\title{
THE IMPLEMENTATION OF STANDARDS OF EDUCATORS AND EdUCATION PERSONNEL IN SMP NEgERI 1 SUNGai RAYA KUBU RAYA REGENCY
}

\author{
Lamazi $^{1)}$, Maswardi.M.Amin ${ }^{2)}$, M.Chiar ${ }^{3)}$ \\ ${ }^{1)}$ Universitas Tanjungpura, Pontianak, Indonesia \\ E-mail:lamaziasrin@gmail.com \\ ${ }^{2)}$ Universitas Tanjungpura, Pontianak, Indonesia \\ E-mail: maswardi.mamin@gmail.com \\ ${ }^{3)}$ Universitas Tanjungpura, Pontianak, Indonesia \\ E-mail: chiarfkip@gmail.com
}

\begin{abstract}
This study aims to obtain comprehensive information on the Implementation of Standards of Educators and Education Personnel in SMP Negeri 1 Sungai Raya Kubu Raya Regency related to How the Standards of Educators and Education Personnel and any factors that inhibit and support in implementing it and what efforts are made by the Headmaster in implementing the Standards of Educators and Education Personnel in SMP Negeri 1 Sungai Raya Kubu Raya Regency. This research is descriptive qualitative research. The data source consists of Headmaster, Educators and Education Personnel. The data collection procedure is done by observation, structured and in-depth interviews, and documentation. Validity checking the results is performed by member check, reference sufficiency, and triangulation. Data analysis used is a qualitative analysis that is by describing and interpreting data. The result of the conclusion is as follows: (1) Work Program of Educator Standard and Education Personnel at SMP Negeri 1 Sungai Raya Kubu Raya Regency has been running well, (2) Education Standard and Education Personnel in SMP Negeri 1 Sungai Raya Kubu Raya Regency also very good, because in terms of applying these standards the Headmaster does not have difficulties, as all school personnel have an awareness of their duties and responsibilities. (3) Communications conducted in implementing the Standards of Educators and Education Personnel in SMP Negeri 1 Sungai Raya Kubu Raya Regency is also well underway. (4) The supporting factors faced by the Headmaster in implementing the Standards of Educators and Education Personnel at SMP Negeri 1 Sungai Raya Kubu Raya Regency are all Educators and Education Personnel meet the Educational qualifications required by the Government and the educator has been certified. The inhibiting factor is lack of library personnel who specifically manage the library and laboratory professionals in their field. How to overcome these obstacles is the Headmaster provides an additional duty to the teacher to become head of the library and the laboratory, meanwhile for library staff and laboratory personnel the school assigns the honorarium. (5) The Headmaster's efforts in implementing the Standards of Educators and Education Personnel at SMP Negeri 1 Sungai Raya of Kubu Raya Regency is by involving them in the preparation of the RKAS, establishing TPS and TPK, IHT, actively encouraging in the MGMP. Educators and Education Personnel improve their academic qualification and competency standards through various activities, including further studies, partnerships with other schools, programmed discussions, etc. The competence owned Educator, of course, affects the learning process and improving the quality of learners learn.
\end{abstract}

Keywords: Implementation; Standards; Educators; Education Personnel 


\section{INTRODUCTION}

Education is a process that aims. Any process that aims, of course, has the size already up where our education journey in reaching a goal. In contrast to physical goals such as the distance of a place or a production target, the purpose of education is an intangible and constantly changing and increasing. The purpose of education is always temporary or a running goal. This means that educational goals at all times need to be revised and adjusted to the demands of change. In the context of Indonesian national education, a standard that needs to be achieved within a certain period of time in order to realize the goal of education. This means the need for clear and focused and feasible formulation of educational objectives. The formulation of educational goals can be the ideal goals, long-term goals, medium-term goals and strategic plans that look with the circumstances and time.

The formulation of the educational objectives was formally legalized by Law Number 20 the Year 2003 on National Education System where its implementation is spelled out in a number of regulations such as Government Regulation Number 19 the Year 2005 which is now replaced by Government Regulation Number 32 the Year 2013 on National Education Standard. This Government Regulation provides guidance on the need to develop and implement eight national standards of education, of which one of the standards is the standard of Educators and Education Personnel.

Education is also an important factor in shaping and improving the quality of human resources as development filling personnel in accordance with National Education Goals. The purpose of National Education is to develop the quality of human resources as early as possible in a directional, integrated and comprehensive through various productive and creative efforts by all components of the nation so that young people can develop optimally. Personnel directly related to the task of providing education is Educators and Education Personnel. In performing its functions and duties, the teacher as a profession holds certain requirements as stated in the Law of the Republic of Indonesia Number 20 the Year 2003 on National Education System.

The government's policy on education is one of the concerns in Law Number 20 the Year 2003 regarding National Education System, which includes the basic and objectives, the implementation of education including compulsory education, the guarantee of the quality of education and the participation of the community in the national education system. The policy was created to produce a good Indonesia Education and qualified graduates in the education sector. In order to support it, the government must issue Government Regulation No. 32 of 2013 as a substitute of Government Regulation No. 19/2005 on National Education Standards (SNP). Educators and Education Personnel as an operational and mental stakeholder should be prepared and upgraded professionally, because only then can their performance be effective. If the standards of Educators and Teachers are in accordance with the National Standards of Education, then the purpose of education will be achieved.

The purpose of National Education is to educate the life of the nation and develop a complete humanity of Indonesia, that is the man who is faithful and devoted to God Almighty and virtuous noble character, possessing knowledge and skills, physical and spiritual health, solid and independent personality and sense of community responsibility and nationality. According to Sudarwan Danim (2013: 10) Teachers (Educators) and Education Personnel plays a central role in the success of Education for All, EFA and Praxis (practice and strategic) Quality education.

Educators and Education Personnel as an operational and mental stakeholder should be prepared and upgraded professionally, because only then can their performance be effective. If the Standards of Educators and Education Personnel are in accordance with the performance and have been effective, then the goal of education will be achieved. To achieve the goal of education in a school, it is necessary that the standard of educator and educational personnel in accordance with the provisions of the applicable legislation as mentioned above.

One of the Schools which have applied the Standards of Educators and Education Personnel is SMP Negeri 1 Sungai Raya Kubu Raya Regency as one of the formal educational institutions that exist in the Department of Education and Culture Kubu Raya Regency, held to realize the founding mandate of the state as contained in the 1945 Constitution in order to educate the life of the nation Implementation of education in SMP Negeri 1 Sungai Raya Kubu Raya Regency is expected in accordance with national standards of education, especially regarding to the Standards of Educators and Education Personnel as stipulated in Government Regulation No. 19 of 2005 viewed from the minimal criteria of the Standards of Educators and Education Personnel in entire jurisdiction of the Unitary State of the Republic of Indonesia. Because educators or teachers play a central and strategic role in the learning process in school.

In the implementation of SMP Negeri 1 Sungai Raya, the lesson is taught by 39 state teachers or civil servants and 7 non-state teachers, assisted by the administrative staff of 8 state employees and 2 non-state employees. Based on the author's 
observation, all educators have the competence to meet the criteria required by the government.

Based on the Regulation of the Minister of National Education of the Republic of Indonesia Number 16 Year 2007 regarding Academic Qualification and Teacher Competency Standards that teachers in Junior High Schools / Islamic Junior High Schools or other equivalent forms must have a minimum education qualification of Diploma-IV or Bachelor Degree studies that match the taught subjects, and obtained from an accredited course of study.

Quality of Educators and Education Personnel will have an impact on the implementation of education in the school. Therefore, the authors want to know the Implementation of Standards of Educators and Education Personnel in SMP Negeri 1 Sungai Raya Kubu Raya.

\section{LITERATURE REVIEW}

Definition of Educator according to Law Number 20 of 2003 Article 39 paragraph 2 states that educators are professionals in charge of planning and implementing the learning process, assessing learning outcomes, conducting guidance and training, and conducting research and community service, especially for educators at universities high.

Understanding Teachers or educators in Law number 14 the Year 2005 on Teachers and Lecturers that the teacher is a professional educator with the main task of educating, teaching, guiding, directing, training, assessing and evaluating learners in early childhood education through the formal education of basic education and secondary education.

Hamzah B.uno and Nina Lamatenggo (2015: 2) Formally, teachers are teachers in both public and private schools who have capability based on formal education at least undergraduate status, and legal provisions as teachers based on teacher and lecturer laws applicable in Indonesia. Meanwhile, according to Sudarwan Danim (2013: 17), The teacher is a professional educator with the main task of educating, teaching, guiding, directing, training, assessing, and evaluating learners on the formal education path. And according to Syaiful Sagala (2013: 6) Teachers as educators are the most widely associated figures and interact with students compared to other personnel in the school. And according to him again the teacher in charge of planning and implementing the learning process, assessing the learning outcomes, conduct guidance and training, conduct research and assessment, and open communication with the community. Then according to Muhammad Asri Amin (2013: 17) The general meaning of "a teacher" is someone who stands in front of the class, teaching about a certain knowledge and skills to students who come to learn.
And according to Jamil Suprihatiningrum (2013: 23) Teachers are called professional educators because the teacher has received and bear the burden of parents to participate in educating children. Meanwhile, according to Donni Juni Priansa (2014: 35) Etymologically, the term Guru derives from an Indian language which means a person who teaches about deliverance from misery. Then Hamzah B. Uno and Nina (2016: 1) In general teachers are educators and teachers for early childhood education of school paths or formal, basic, and secondary education. Further Mulyasa (2017: 37) Teachers are educators, who become role models, role models, and identification for learners, and the environment. Therefore, teachers must have certain personal quality standards, which include responsibility, prestige, independence, and discipline.

Furthermore, this understanding of Teachers or Educators is proposed by Sholeh Hidayat (2017: 1) The Teacher is one of the human components in the learning process that plays a role in the effort of potential human resources development as the investment in development field through if mindset, taste, and sports.

Furthermore, the definition of Teachers according to Law No. 20 of 2003 article 1, chapter 1 (General provisions) Teachers are members of society who are devoted and appointed to support the implementation of education. Furthermore, in article 39, paragraph 1 explained the Teaching Staff in charge of implementing the administration, management, development, supervision, and technical services to support the educational process in the educational unit. Then according to Murip Yahya (2013: 19), Educational Personnel is a job done by someone related to the process of organizing Education that can produce and be done with certain skills, skills, and skills and based on the prevailing norms.

Professional Educators and Educational Personnel are the determinants of quality educational processes. Effective Management of Educators and Teachers should be seen that the development of Educators and Education Personnel is part of national development. An overall HR development, as well as looking at the relationships of the various components that influence each other.

To facilitate the understanding of the Definition of the Standards of Educators and Teaching Personnel in a theoretical study, the Researcher will explain one by one as follows:

According to Wirawan (2011: 278), Standard is a principle agreed by people who are engaged in professional practice. Meanwhile, according to Cambridge Advanced Learner's Dictionary (2008: 1412) Standard is a level of quality and a moral rule which should be obeyed (Standard is the level of quality and moral rules that must be obeyed). 
According to Wina Sanjaya (2016: 8) Furthermore, the standard of educator will determine the qualification of each teacher as professionals who can support the successful achievement of educational goals. Standards of Educators and Education Personnel according to Regulation of the Government of the Republic of Indonesia Number 32 the Year 2013 Amendment To Government Regulation Number 19 the Year 2005 About National Standards of Education The Standards of Educators and Education Personnel are criteria on pre-service education and feasibility and mental, as well as inservice education. According to Maswardi (2016: 81), Educator Standards and Education Personnel in question is the minimum level of Education that must be met by Educators and educational personnel who are declared by having a relevant diploma or certificate of expertise under the applicable provisions.

The Headmaster is a functional teacher who is given the additional task to lead a school, where the learning process is organized or where there is an interaction between the teacher giving the lesson and the student receiving the lesson. With this Headmaster can be said as a leader in the educational unit whose task is to run the management of educational units led. At the operational level, the Headmaster is the person at the forefront who coordinates efforts to improve quality learning. The Headmaster is appointed to positions in charge of coordinating joint efforts to achieve educational goals at the school-led level. The Headmaster has a role that greatly influences the running of the existing system within the school.

The headmaster is responsible for the implementation of education, school administration, coaching other education personnel, utilization, and maintenance of facilities and infrastructure as well as a supervisor at the school he leads. When viewed from the requirements of teachers to become Headmasters. The Headmaster can be said to be the career path of the functional position of the teacher. If a teacher has a competence as a Headmaster and has met certain requirements or tests then the teacher can obtain the position of Headmaster.

According to Peter (2013: 5) said that "leadership is the process by which individuals affect a group of individuals to achieve common goals". Fred E. Fielder \& Martin Chammers in Wahjosumidjo (1999: 19) states that "leadership issues are basically inseparable from three things: (1) how one becomes leader (2) how leaders behave (how leader behave), and (3) what makes the leader work (what makes the leader effective) ".

Simply implementation can be interpreted implementation or implementation. Implementation is also defined as an action or execution of a wellcrafted and detailed plan. Implementation is usually done after the planning is considered fixed. Below are some definitions of implementation. According to Van Meter and Van Horn in Wahab (2005: 65) Implementation is actions undertaken either by individuals/officials or government or private groups directed at achieving the objectives outlined in policy decisions. Meanwhile, according to Indonesian Dictionary (2008: 548) that Implementation is the implementation; application. Then according to Mulyasa (2015: 178) Implementation is a process of applying ideas, concepts, policies, or innovations in a practical action so as to give impact, either in the form of changes in knowledge, skills, values, and attitudes. Furthermore, Charles O. Jones in Rusdiana (2015: 132) who bases himself on the concept of functional activity argues that implementation is an activity intended to operate a program. Then Erwan Agus Purwanto and Diah Ratih Sulistyastuti (2015: 21) Say that Implementation is an activity to distribute the policy output (to deliver policy output) conducted by the implementers to the target group as an effort to realize the policy objectives.

\section{METHODOLOGY}

This research uses a qualitative approach. Qualitative data analysis is conducted throughout the study from beginning to end, without having to wait for all data to collect. The data analysis activity begins by examining the amount of data available from various sources, i.e. the results of interviews, observations, documentation. Presentation The data in this study collects structured information that gives the possibility of conclusion and action taking. By looking at the data on the implementation of educator standards and education personnel at SMP Negeri 1 Sungai Raya Kubu Raya Regency, we will be able to understand what is going on and what to do further analyze or take action based on the understanding gained and the presentations the.

The analysis was conducted on all data and information obtained through interviews, observation and document collection on the implementation of educator standards and education personnel in SMP Negeri 1 Sungai Raya Kubu Raya Regency. The Researcher analyzed the results of the interviews based on an understanding of the things expressed by the respondents, the results of observation data and documentation during the data collection process. The data have been grouped by the Researcher understood in full and found important themes and keywords. So that Researcher can capture the experiences, problems, and dynamics that occur in the subject.

\section{RESULTS AND DISCUSSION}

Obtaining the meaning of each formulation of the findings, following this researcher did the discussion. In this discussion, the researcher presents 
the data of the findings then studies them using various theories, and expert opinions. Through the study conducted, researcher tried to give meaning to the findings. Researcher hopes the meaning of the findings will be useful for all concerned. Therefore, this chapter describes the Researcher: (A) Discussion of Research Findings, continued (B) Meaning of Research Results.

In the discussion of the findings, the researcher revealed various findings in accordance with the research focus. Each research findings, Researcher discussed and refers to the theory that has been presented. The following is a discussion of the findings data related to Implementation of Standards of Educators and Education Personnel at SMP Negeri 1 Sungai Raya Kubu Raya Regency.

A. Work Program of Teachers and Education Standards at SMP Negeri 1 Sungai Raya

Work programs in implementing the Standards of Educators and Education Personnel are 1. Establish TPS and TPK 2. Hold Classroom Supervision to improve teachers' teaching ability or educators. 3. Conducting Routine Meetings in the evaluation of learning activities and up-to-date information. 4. Conducting IHT (In-House Training) in schools in order to improve the competence of Educators and Education Personnel.

B. Standards of Educators and Education Personnel at SMP Negeri 1 Sungai Raya

Based on the results of observations and interviews among the Researcher with the headmasters, educators and educational staff that the academic qualifications and competence of Educators and Education Personnel also determine the success of education, therefore, the academic qualifications of Educators and Education Personnel can show that the high quality of education. Quality of Educators and Education Personnel will have an impact on the implementation of education in the school. Therefore, the researcher wants to know the Implementation of Education Standard and Education Personnel in SMP Negeri 1 Sungai Raya Kubu Raya Regency.

C. Communication is undertaken in implementing the Standards of Educators and Education Personnel in SMP Negeri 1 Sungai Raya Kubu Raya Regency

Communications conducted by the Headmaster, Educator and Staff Personnel are as follows: 1. Encouraging and inviting Educators and Education personnel to carry out their duties in the best way. So, the creation of a conducive learning climate will be orderly, fluently, and effectively. 2 . Communicating with the parents' learners as partners and building collaboration for the benefit of the learning process of learners.

D. Factors that inhibit and support in implementing the Standards of Educators and Education Personnel in SMP Negeri 1 Sungai Raya Kubu Raya Regency
Based on the findings of Researcher at SMP Negeri 1 Sungai Raya, that the supporting factor is the academic qualifications of Educators and Teachers already meet the standards set by the government and all the educators here are certified. Then Educators and Education Personnel also have loyalty and discipline that is high enough and good performance, they are aware because it has got a certificate of educators and want to become a professional Personnel so there is no difficulty in empowering it. While the inhibiting factor is that is still lack of library staff and professional laboratory in its field.

In line with that Hendarman (2015: 3) said, "good Headmasters are expected to form a process of learning by teachers to be good". Good Headmaster leadership should be able to create conditions that allow for the birth of a harmonious and conducive Work climate and human relations. If the learning in the school well, of course, will produce good achievement also both the students and teachers.

E. Efforts made by the Headmaster in implementing the Standards of Educators and Education Personnel at SMP Negeri 1 Sungai Raya Kubu Raya Regency

Related to the ways in which the Headmaster performs the standards of educators and education personnel, Sudarwan Danim and Khairil (2015: 30) Teachers and professional education personnel undergo a process of continuous development and development. Applying the Headmaster's discipline there is no difficulty because all school personnel has an awareness of their duties and responsibilities. According to Edward Sallis (2010: 174), An important aspect of the leadership role in Education is to empower teachers and give them broad powers to improve the learning of learners.

Motivation, praise, and rewards are always done by the school Headmaster to all the school residents who excel. Establish communication with teachers and administrative staff on various matters, which do at every opportunity, such as rest period, then every Saturday always holds the meeting which discusses various things for school progress. Then hold a coordination meeting every month.

This is in accordance with the opinion of Wibowo (2014: 111), "Motivation is the impetus to act on a series of processes of human behavior by considering direction, intensity, and perseverance on achieving goals". Next Schunk (2014: 4) The term motivation is derived from the Latin verb movere (to move). The idea of movement is reflected in that common idea about something that gets us going, keeps us Work, and helps us complete tasks. Understanding this motivation is also confirmed by Business Dictionary in Suyono and Hariyanto (2015: 183) Motivation is defined as internal and external factors that encourage human desire and energy to continuously put interest and attention to the work, its 
role, or to a particular subject, and giving a genuine and persistent effort in achieving those goals. So, Motivation is a process to activate motives into actions or behavior to meet the needs and achieve goals, or state of readiness within the individual that encourages his behavior to do something in achieving certain goals. Praise and reward mean that if there are successful educators and education personnel who successfully complete the task well, should be given praise in the form of positive reinforcement and motivation at the same time. Giving it must be appropriate, with the right praise will foster a pleasant atmosphere and enhance the passion of work.

\section{CONCLUSIONS}

Based on the results of observations and interviews of Researcher with Headmasters, educators and education personnel can be concluded that:

a. The Work program in implementing the Education Standards and Education Personnel in SMP Negeri 1 Sungai Raya Kubu Raya Regency has been running well, programmed and directed.

b. Standards of educators and education personnel who have been applied in schools already meet the provisions of both the academic qualifications and the competence of Educators and Education Personnel so that helped determine the success of the learning process itself.

c. Communication between school Headmaster, educators and education personnel and parents of students who have been implemented in schools are running well so that the achievement of a conducive learning climate, orderly, smooth, and effective.

d. Supporting factors in the implementation of educator standards and education personnel are all that all educators are certified and have high loyalty and discipline with good performance. With awareness and passion to be more professional in carrying out their duties. While the inhibiting factor is that there is no laboratory libraries and laboratory personnel in their field in managing libraries and laboratories.

e. Efforts made by the Headmaster in implementing the Standards of Educators and Education Personnel in SMP Negeri 1 Sungai Raya Kubu Raya Regency is to provide guidance and support to Educators and Education Personnel to be able to excel.

\section{REFERENCES}

Abdul Wahab, Solichin. 2005. Analisis Kebijakan Dari Formulasi Ke Implementasi Kebijaksanaan Negara. Jakarta: PT. Bumi Aksara.

Afifuddin, Saebani Beni Ahmad. 2009. Metodelogi Penelitian Kualitatif. Pustaka Setia.

Agus Purwanto, Erwan dan Dyah Ratih Sulistyastuti. 2015. Implementasi Kebijakan Publik Konsep dan Aplikasinya di Indonsia. Yogyakarta: Penerbit Gava Media.

Arikunto, Suharsimi. 2013. Prosedur Penelitian, Suatu Pendekatan Praktik. Jakarta: PT. Rineka Cipta.

Asri Amin, Muhammad. 2013. Menjadi Pendidik Profesional (Disertai Bimbingan Menjadi Pelatih Andal). Bandung: Penerbit Nuansa Cendekia.

Bogdan, Robert. 1992. Qualitative Research For Education. Biklen: Sari Knoop.

Cambridge University. 2008. Cambridge Advanced Learner's Dictionary Third Edition. Singapore: Cambridge University Press.

Danim, Sudarwan. 2013. Profesionalisasi dan Etika Profesi Pendidik. Bandung: Alfabeta.

Danim, Sudarwan \& Khairil. 2015. Profesi Kependidikan. Bandung: Alfabeta

Emzir. 2016. Metodologi Penelitian Kualitatif ANALISIS DATA. Depok: PT. Rajagrafindo Persada.

Glickman Carl D. 2002. Leadership for Learning. Bibliographical Inc.

Hasan Basri. 2014. Kepemimpinan Kepala Sekolah. CV. Pustaka Setia.

Hendarman. 2015. Revolusi Kinerja Kepala Sekolah. PT. Indeks

Hidayat, Sholeh. 2017. Pengembangan Pendidik Profesional. Bandung: PT. Remaja Rosdakarya.

Hidayati. 2014. Jurnal. Manajemen Manajemen Manajemen Manajemen Pendidikan, Fakultas Tarbiyah dan Keguruan IAIN IB Padang, Indonesia.

H. Ahmad, Rusdiana. 2015. Kebijakan Pendidikan "dari Filosofi ke Implementasi". Bandung: CV. Pustaka Setia.

Imeng Minol. 2013. Tesis. Perencanaan Rekruitmen Pendidik dan Tenaga Kependidikan Pesantren Nahdhatul Islam Duri-Riau. UIN Sultan Syarif Kasim.

Jauharotul Muniroh, Muhyadi. 2017. Jurnal. Manajemen Pendidik Dan Tenaga Kependidikan Di Madrasah Aliyah Negeri Kota Yogyakarta. Manajemen Pendidikan PPs UNY, Universitas Negeri Yogyakarta.

Juni Priansa, Donni. 2014. Kinerja dan Profesionalisme Pendidik Fokus pada 
Peningkatan Kualitas Pendidikan, Sekolah dan Pembelajaran. Bandung: Alfabeta.

Jumali. 2016. Tesis. Implementasi Pengembangan Keprofesian Berkelanjutan bagi Pendidik Pendidik bersertifikasi Pendidik di SMK Bhinneka Karya Simo Boyolali. Publikasi Ilmiah.

Mahmud. 2011. Metode Penelitian Pendidikan. CV. Pustaka Setia.

Miles, B. Matthew dan Huberman, A. Michael. 1992. Qualitative Data Analysis, Diterjemahkan oleh Rohidi, Tjejep Rohendi. Jakarta: UIPress.

Moleong, Lexy. J. 2017. Metodologi Penelitian Kualitatif. Bandung: Remaja Rosdakarya.

Muhammad Amin, Maswardi \& Yuliananingsih. 2016. Manajemen Mutu; Aplikasi dalam Bidang Pendidikan. Joqyakarta: Media Akademi.

Muhammad Yusri Bachtiar. 2016. Jurnal. Pendidik dan Tenaga Kependidikan. PG-PAUD Fakultas Ilmu Pendidikan UNM.

Mulyasa. 2015. Implementasi Kurikulum Tingkat Satuan Pendidikan Kemandirian Guru Dan Kepala Sekolah. Jakarta: PT Bumi Aksara.

Mulyasa. 2017. Menjadi Guru Profesional Menciptakan Pembelajaran Kreatif dan Menyenangkan. Bandung: PT Remaja Rosdakarya.

Northouse. Peter G. 2013. Kepemimpinan: Teori dan Praktik. Penerjemah Ati Cahayani

Nur Aedi. 2016. Manajemen Pendidik \& Tenaga Kependidikan. Yogyakarta: Gosyen Publishing

Nurdin, Diding dan Imam Subawih. 2015. Pengelolaan Pendidikan dan Teori menuju Implementasi. Jakarta: PT. RajaGrafindo Persada.

Peraturan Pemerintah Nomor 32 tahun 2013 perubahan PP Nomor 19 Tahun 2005 Tentang Standar Nasional Pendidikan.

Peraturan Pemerintah No. 38 Tahun 1992 tentang Tenaga kependidikan.

Permendiknas Nomor 16 tahun 2007 tentang Standar Kualifikasi Akademik dan Kompetensi Pendidik.

Permendiknas Nomor 13 Tahun 2007 tentang Standar Kepala Sekolah/Madrasah.

Permendiknas Nomor 24 Tahun 2008 tentang Standar Tenaga Administrasi Sekolah.

Permendiknas Nomor 25 Tahun 2008 tentang Standar Tenaga Perpustakaan Sekolah/Madrasah.

Permendiknas Nomor 26 Tahun 2008 tentang Standar Tenaga Laboratorium.

Sagala, Syaiful. 2013. Kemampuan Profesional Pendidik dan Tenaga Kependidikan. Bandung: Alfabeta.

Saebani, Beni Ahmad. 2016. Metode Penelitian. Bandung: CV. Pustaka Setia.
Sallis, Edward. 2010. Total Quality Management in Education. Jogyakarta: IRCiSoD. Alih Bahasa.

Sanjaya, Wina. 2016. Strategi Pembelajaran Berorientasi Standar Proses Pendidikan. Jakarta: Prenadamedia Group.

Schunk, Dale H. 2014. Motivation in Education: Theory, Research, and Application.USA: Pearson Education.Inc.

Sugiyono. 2013. Memahami Penelitian Kualitatif. Dilengkapi contoh Proposal dan Laporan Penelitian Bandung: Alfabeta.

Sugiyono. 2016. Metode Penelitian Administrasi dilengkapi dengan Metode $R \& D$. Bandung: Alfabeta.

Sugiyono. 2015. Metode Penelitian Pendidikan (Pendekatan Kuantitatif, Kualitatif dan $R \& D)$. Bandung: Alfabeta.

Sugiyono. 2016. Metode Penelitian Kuantitatif Kualitatif dan $R \& D$. Bandung: Alfabeta.

Suprihatiningrum, Jamil. 2013. Guru Profesional: Pedoman Kinerja, Kualifikasi \& Kompetensi Pendidik. Jogjakarta: Ar-Ruz Media.

Suyono dan Hariyanto. 2015. Implementasi Belajar dan Pembelajaran. Bandung: PT. Remaja Rosdakarya.

Undang-Undang Nomor 20 Tahun 2003 tentang Sistem Pendidikan Nasional

Undang-Undang nomor 14 Tahun 2005. Tentang Guru dan Dosen.

Uno, B. Hamzah dan Nina Lamtenggo. 2016. Tugas Guru dalam Pembelajaran: Aspek yang memepengaruhi. Jakarta: PT. Bumi Aksara.

Wahjosumidjo. 1999. Kepemimpinan Kepala Sekolah (Tinjauan Teoritik dan Permasalahannya). Jakarta: RaraGrafindo Persada

Wibowo. 2013. Perilaku dalam Organisasi. PT. Rajagrafindo Persada. Jakarta

Wirawan. 2011. EVALUASI: Teori, Model, Standar, Aplikasi, dan Profesi Contoh Aplikasi Evaluasi Program: Pengembangan Sumber Daya Manusia, Program Nasional Mengimplementasikan Standar Pendidik dan Tenaga Kependidikan Masyarakat (PNPM) Mandiri Perdesaan, Kurikulum, Perpustakaan, dan Buku Teks. Jakarta: PT. Rajagrafindo Persada.

Tim Penyusun. 2008. Kamus Bahasa Indonesia. Jakarta: Pusat Bahasa.

Yahya, Murip. 2013. Profesi Tenaga Kependidikan. Bandung: CV. Pustaka Setia.

Yin. Robert K. 2013. Studi Kasus: Desain \& Metode. Depok: Rajawali Pers. 